\title{
Editorial
}

\section{Brands in a digital world}

According to our latest research at London Business School, experts on the future of the media expect 60 per cent of transactions to be online in ten years' time for retail banks, travel agents, airlines and mail-order clothing firms. For music, books and newspapers, the proportion is expected to be about 30 per cent, and for groceries, about 15 per cent. Even for cars, high-street clothing retailers and white goods (appliances), the proportion is expected to be ten per cent. These expectations are broadly similar for experts in the UK, North America and Continental Europe.

The experts may be wrong. Perhaps online transactions will fail to take off in some of these industries. Perhaps the proportion of online transactions in banking, air travel and music will be 'only' 20 per cent in 2006, not 60 per cent. No one knows, but what is undeniable is that there is a good chance that a significant proportion of transactions in many consumer goods and services categories will be online in a few years' time and that many of these transactions will involve actual brand choice.

What will these changes mean for brands and brand values?

\section{WHAT IS NEW ABOUT ONLINE SHOPPING?}

Home shopping is not new. Mail order goes back 150 years (and was already a huge business in the USA by 1900), and upscale consumers have occasionally ordered tickets or groceries by telephone since well before World War II. What is different about online then? Four things.

\section{Availability}

First, until now, most category and brand choice has been at a retail outlet, either by self-service and direct inspection (as in a supermarket, bookstore, music store, or newsagent); or with the help of sales staff (as in a hi-fi store or travel agent). In some categories, choosing a brand goes with choosing an outlet (eg cars, gasoline, high street banks, restaurants or private label groceries).

In all of these cases, availability is a crucial driver of brand choice and, therefore, brand value: ask Gillette, or Kodak, or P\&G, or Mars, or Coca-Cola, or McDonald's, or Bass, or Holiday Inn, or Shell, or Visa, or Matsushita, or Sharp, or Duracell, or Honda, or even the Financial Times. In these cases, God is very much on the side of the big battalions. But on the Internet, a one-person business can make its electronic shop window available to as many consumers as GM, Sony, or Coke.

\section{Real-time information and interaction}

Second, online shopping uniquely combines the best features of mail order and telephone shopping.

Mail order, especially catalogue shopping, allows the consumer at home to evaluate and compare competing brands using still pictures and text. But mail order has limited interactivity, because its response times are measured in days or weeks.

The most sophisticated direct marketers are increasingly adapting their communications and product offerings in response to earlier interactions with individual consumers and segments. But regular mail can never provide real-time interaction and is 
ill-suited to dialogue involving open-ended questions, eg the consumer asking for advice on holidays, or the travel agent asking questions to clarify the kind of holiday being sought. This open-ended dialogue is crucial to making markets work, especially for infrequently-purchased categories.

Conversely, the telephone is highly interactive, but gives the consumer very limited information. Between-brand comparisons require the consumer either to trust one seller or agent or to call up several.

\section{Information processing and selection}

Third, online technology allows information about competing brands to be processed by the system and selected and presented in many different ways, not just disseminated in a fixed format as in a catalogue. For instance, an online system can allow you to limit your search of a category to products or services with a specific list of attributes, including maximum price. For groceries, it can let you start with a standard basket of goods and then add extra items; or provide (or even rank the brands on) nutritional information or prices per gram; or highlight special offers.

A sophisticated system with 'intelligent agent' sof tware can even give you recommendations based on your personal characteristics and previous product/brand choices: the MIT spinoff Firefly does this for music CDs. If you choose to do so, you can then delegate purchasing authority to the agent.

In other words, come the digital revolution, in some cases the customer will not be a person, but a software agent in a computer. This has been happening in businessto-business markets for some years, but is now starting in consumer markets too.

\section{Low-cost global reach}

Fourth, online markets can easily be globalised - provided that there is a way of delivering the product or service worldwide.
Strictly speaking, mail order and telephone shopping can also be global, but historically they have mostly been national, for a number of boring practical reasons. In the case of telephone shopping this may change because of the collapsing cost of international calls. In a few years, your local FedEx call centre may be in China, manned 24 hours a day.

But, FedEx's virtual private network, which enables customers to track every shipment online, is already global, at the cost of a local call, 24 hours a day.

Global delivery of most products and services is still a big issue. For electronic products or those that can be easily sent by mail, the technical barriers are low. But even in these cases, there can be regulatory or tax barriers: despite the cyberhype, the nationstate still exists for products that are big, or need to be fresh, and for services that require personal delivery, you need local distribution for all customers in your market, along the lines of Domino's pizzas locally or Interflora globally.

For items like groceries, the markets will always be largely local and new logistical systems will need to evolve, perhaps including external cold storage on houses, or a revival of the tradesman's entrance, or concierges, or local collection points, or whatever. In apparel, we may see a mushrooming of local alteration services. It is still early days. But the trend towards global online consumer markets is clear.

\section{SHOPPING ON PRICE}

The spectre that haunts discussion of online shopping is the threat of ferocious price competition destroying margins.

The way that online technology enables consumers to shop globally, easily compare products and prices, search for special deals and so on, does give them the power to find the best value for money - in some cases, anywhere in the world. This represents three potential threats to brands. 
First, online shopping threatens the very existence of some businesses or even industries, especially agents or brokers whose business is based on matching individual consumers' needs to best-value market offerings. If the consumer can directly find the best-value car insurance or packaged holiday, the only way an agent or broker can create value is by providing something extra, like outstanding claims handling, legal services, or intimate and up-to-date knowledge of Majorcan hotels and night life. Last year, over 15 per cent of packaged holidays from the UK were sold via direct response advertisements on Teletext.

Less apocalyptically, retail banks with costly branch networks (currently making tons of money) are already looking for ways to maximise the customer value of these branches in the face of competitive attack by foreign banks, various non-banks moving into banking, and telephone banks - before any serious entry by online banks. Of course, if 60 per cent of retail banking transactions really were online by 2006 (which seems to me highly unlikely), the effect on branch-based banks would indeed be catastrophic.

Second, what The Economist has called 'the death of distance' will lead to some levelling of prices between countries and regions - not for haircuts but maybe for consumer electronics, PCs, CDs, plane tickets, clothes, international telephone calls and many other categories.

Third, consumers' increased ability to compare prices will accelerate the decline of any brand within a category which offers neither superior value for money nor unique tangible or intangible benefits. This worries all marketers.

\section{ARE THESE FEARS EXAGGERATED?}

Some of these fears seem to me exaggerated.

It will take some years before most homes are online, even in the USA. (However, those that are online will tend to be upscale and some of the rest will have online access at work or through friends, if the benefits justify the effort.)

There is a lot of inertia in most markets. People rarely switch banks. The techno-enthusiasts always exaggerate consumer involvement and the rate of change. (But even if change may take longer than predicted, it can still be just as dramatic in its long-term impact.)

There are technical and regulatory barriers. Windows 95 is still too complex for the mass market, printers don't print, the Internet is slow, insecure and unreliable, shipping a PC from the USA to Europe involves hassle and tax. (But most of these problems will be much reduced in only 2 or 3 years.)

Even the argument that the Internet provides a level playing-field for large and small players has been overstated. Building a Web site that people will want to visit and keep coming back to is costly. So is advertising to attract traffic. Also, as the Internet evolves into a 2- or 3-tier system, firms and/or consumers will have to pay in order to sell or buy via a faster, betterquality network. (Nevertheless, online technology undoubtedly provides many opportunities for new entrants and we have evidence from previous new technologies that incumbent firms usually respond too little, too late and with the wrong technical choices.)

Finally, the fear that online shopping will expose brands that are poor value for money assumes that such brands are not already exposed - as if branding were an alternative to value for money. On the contrary, I see brands as a way of simplifying consumers' choices in an over-communicated and untrustworthy world, by providing consistent, reliable quality and value for money and in some cases intangible benefits as well. If the brand owner fails to deliver on quality or pushes the price premium unjustifiably high, brand value will be destroyed. (But online 
shopping may accelerate this process in some contexts.)

Overall, then, some of the threats to existing brands and businesses posed by online shopping seem to be overstated, especially in terms of timescale. But the long-term threats are still real, particularly for firms such as travel agents, insurance brokers, high-street banks, bookshops and music stores.

\section{THE IMPACT ON BRANDS}

None of this means that the role of brands will be less in a digital world. Leaving aside the question of how digital the world will actually be, and how soon, it will certainly be at least as over-communicated as now especially for the most valuable (money-rich, time-poor) consumers. Doubtless it will also be as untrustworthy as it has always been.

The technology will simplify the search for products, but this will be countered by everincreasing information overload. Brands will, therefore, still have a key role in simplifying the purchase process. The technology will also accelerate the loss of sales and margin for uncompetitive brands, reinforcing the need to keep investing in the product and the brand and to keep prices within reasonable bounds. This is hardly new: Marlboro Friday had nothing to do with the Internet.

Above all, any kind of remote purchasing increases the role of brands as a guarantee of quality and service: consumers will need to trust both product suppliers and intermediaries.
Take car insurance, for example. Suppose I can use software on my PC or service provider to search for the cheapest offer that meets my specification. Leaving aside the fact that I need to believe that the software (or service provider) has got things right for which a strong brand will help - I will still be cautious about buying cut-price insurance from a 'no-name' supplier, just the same as now.

In categories with high emotional involvement, the role of brands will be affected even less. An online system can show the cheapest 'place' to buy Nike trainers, Levi 501 s, or a new or second-hand Mercedes. The fact that it will also show cheaper alternatives to these premium brands is unlikely to have much impact on brand choice or even relative prices.

In short, brands are here to stay. Their role could even increase over time as our society becomes even more over-communicated. So, online shopping will not reduce the importance of brands, but it will cause significant reallocation of brand values in many markets, similar to the earlier shift from IBM to Intel and Microsoft. For managers in those markets that will be most affected, the challenge will be to make their brand the Intel of that industry.

Patrick Barwise Editorial Board 
